\title{
CORRELATION BETWEEN LACTIC ACID CONCENTRATION AND THE SEVERITY OF NEONATAL SEPSIS
}

\author{
Agustin Iskandar ${ }^{1}$, Nada Putri Pranidya ${ }^{2}$, Eko Sulistijono ${ }^{3}$, Aryati $^{4}$ \\ Department of Clinical Pathology, Faculty of Medicine, Brawijaya University/Saiful Anwar General Hospital, Malang, Indonesia. E-mail: \\ agustin_almi@yahoo.co.id \\ 2 Medicine Study Program, Faculty of Medicine, Brawijaya University/Saiful Anwar General Hospital, Malang, Indonesia \\ ${ }^{3}$ Department of Pediatrics, Faculty of Medicine, Brawijaya University/Saiful Anwar General Hospital, Malang, Indonesia \\ ${ }^{4}$ Department of Clinical Pathology, Faculty of Medicine, Airlangga University/Dr. Soetomo General Hospital, Surabaya, Indonesia. E-mail:
}

\begin{abstract}
In Indonesia, neonatal sepsis remains a major cause of high infant mortality rate and serve as one of the risk factors for early neonatal mortality. This study aimed to determine of the correlation between lactic acid level, the severity of sepsis, and the prognostic value of lactic acid as a predictor of neonatal sepsis severity. This study was an analytical observational research using cross-sectional method. The subjects were neonatal sepsis patients treated in the Perinatology Room of Saiful Anwar Hospital Malang from February to June 2015. The lactic acid concentration in the plasma was measured using an enzymatic colorimetric method. The results showed a positive and significant correlation $(p=0.023 ; r=0.414)$ between lactic acid concentration and severity of the sepsis, with lactic acid level of $0.151 \mathrm{mmol} / \mathrm{L}$ in every increase of sepsis. By using a cut-off $\geq 2.5 \mathrm{mmol} / \mathrm{L}$, sensitivity and specificity of $66.7 \%$ and $76.2 \%$ were obtained, respectively. The Chi-Square test of lactic acid $>2 \mathrm{mmol} / \mathrm{L}$ and $<2 \mathrm{mmol} / \mathrm{L}$ showed an Odd Ratio (OR) of 1.3. However, lactic acid level $>5 \mathrm{mmol} / \mathrm{L}$ and $<5 \mathrm{mmol} / \mathrm{L}$ showed an OR of 4.8, suggesting that although there was no difference, the mortality outcome of neonatal sepsis was 4.8 times greater than those who survived. Thus, lactic acid levels $>5 \mathrm{mmol} / \mathrm{L}$ was able to determine the mortality outcome of neonatal sepsis. From this study, it was known that severity of neonatal sepsis was higher along with the higher level of the lactic acid. Lactic acid level $>5 \mathrm{mmol} / \mathrm{L}$ was the predictor for the determination of mortality outcome in the neonatal sepsis.
\end{abstract}

Key words: Neonatal sepsis, lactic acid, severity of sepsis

\section{INTRODUCTION}

Neonatal sepsis is a clinical syndrome of systemic diseases, followed by bacteriemia in infants in the first month of life. Neonatal sepsis can occur early, i.e. in the first five to seven (5-7) days with the causative organism obtained during intrapartum or through the mother's genital tract. ${ }^{1}$

The Infant Mortality Rate (IMR) throughout the world is still high and highly occurs at the age of the first month of life (neonatal period) with four (4) million mortality per year and almost $99 \%$ of it are found in the developing countries. The cause of infant mortality in developing countries is infectious disease (42\%). The IMR in Indonesia is also very high about 32 deaths per 1,000 live births. Every hour there is a 10 infant mortality in Indonesia with infection as one of the most common causes. ${ }^{2,3}$

Neonatal sepsis is an emergency condition with ability to cause treatment delay and mortality. The diagnosis and treatment of neonatal sepsis have become more sophisticated in recent years, but neonatal sepsis is still the main cause of neonatal morbidity and mortality. Non-specific initial symptoms are difficult to use in distinguishing between neonatal sepsis and other diseases in neonates. This leads to administration of antibiotic therapy to all suspected sepsis cases. ${ }^{4}$

One of the most common tests used in sepsis diagnosis is positive blood culture. In 2012, the recommended management for severe sepsis was regulated by the Surviving Sepsis Campaign, including lactic acid levels measurement, obtaining blood culture before treatments with broad-spectrum antibiotics, such as $30 \mathrm{~mL} / \mathrm{kg}$ crystalloids for hypotension or lactic acid $>4 \mathrm{~mm} / \mathrm{L}$, and vasopressor. ${ }^{5}$

Lactic acid is a product of cell metabolism which can be accumulated when cells lack of oxygen (hypoxia). Lactic acid is produced by almost all tissues in the human body, with the highest levels foundin the muscle. In normal conditions, lactate clearance is rapidly carried out by the liver with the 
kidneys help. ${ }^{6}$

Lactic acid is a biochemical hallmark of critical illness, trauma, and sepsis. The high lactic level indicates global tissue hypoxia, increased glycolysis, the effect of endotoxin and a sign of anaerobic metabolism. Hypoxic condition is characterized by increased lactic level which also leads to the worse prognosis. Lahat et al. stated that in a hypoxic condition the secretion of Tumor Necrosis Factor (TNF- $\alpha$ ) as the pro-inflammatory mediator increased. Ramanathan et al. suggested that hypoxia could also increase the Vascular Endothelial Growth Factor (VEGF) concentration. Both of them lead to the worse prognosis.?

Many studies have shown that high lactic levels or increased lactic levels on serial examination were associated with an increased risk of mortality in pediatric sepsis patients. ${ }^{7}$ It was also reported that there was a positive correlation between plasma lactate level and severity of organ dysfunction based on the Pediatric Logistic Organ Dysfunction Score (PELOD Score), which showed the composite score and the outcome, and the potential for assessing the severity of organ dysfunction in critically ill children. A critical circumstance can be detected from the number of organ dysfunction found in sepsis patients. $^{8}$

However, the use of lactic acid in the determination of neonatal prognosis of sepsis has not been widely reported. Therefore, further research about the usefulness of lactate levels on the neonatal sepsis prognosis and correlation between lactate level and the sepsis severity was needed.

\section{METHODS}

This study was based on an analytical observational study method which aimed to determine the correlation between the lactic level and sepsis severity and the prognostic value of lactic levels such as sensitivity, specificity, and positive predictive value for the neonatal sepsis.

The subjects of the study were 30 neonatal sepsis patients who admitted to the Perinatology Room in February 2015 and met the inclusion criteria (ages of 0-30 days, term/aterm neonates, body weight of 2,500-4,000 grams, and had clinical and laboratory data) but not exclusion criteria (neonates with congenital abnormalities), and had agreed to take part in the study by signing informed consents.

This study used secondary data recorded by the measurement of blood lactic acid level in blood and clinical examination of patients who met the criteria of suspected neonatal sepsis and treated in the RSSA Perinatology Room.

The data obtained was statistically analyzed using a SPSS 21.0 computer program and one-way ANOVA test with requirement of normally distributed and homogenous data. To determine the data distribution, data variance, and homogenity, a normality test, Shapiro-Wilk test, and Lavene test were carried out, respectively. . If there was a significant difference, then the Tukey Post-Hoc test would be used to determine difference of each treatment group with a significance level of $95 \%$ $(p<0.05)$. If there were significant differences among the groups, the analysis was continued by using Pearson correlation test to determine the correlation between neonatal lactic acid levels and sepsis severity degrees (sepsis, severe sepsis, sepsis shock, and MODS). However, if the data distribution was abnormal or not homogeneous, the Spearman correlation test would be used as the statistic test. ${ }^{9}$

To determine the prognostic value such as sensitivity, specificity, and positive predictive value, a $2 \times 2$ table or a Chi-Square test were used. $p$-value $<0.05$ showed a significant correlation between lactic acid levels and patients'outcome. ${ }^{9}$

Previously, a Receiver Operating Characteristics (ROC) curve analysis was used to determine the recommended Area Under the Curve (AUC) and cut-off values. For the analysis of characteristics, the Mann-Whitney test and Fisher's test were used for determining the sex. p-value $<0.05$ showed significant differences among the groups. However, if the $p$-value was $>0.05$, it was concluded that there was no significant difference among the groups. ${ }^{9}$

\section{RESULTS AND DISCUSSION}

The results of one-way ANOVA test showed significant differences among the groups of sepsis severity degree with the results of $p=0.044(p<0.05)$, suggesting a significant difference in at least two groups of sepsis levels. The results of significant one-way ANOVA test must be followed by a Post Hoc test to determine the differences in each group of the sepsis severity degree.

The Post Hoc test followed by Tukey HSD analysis showed a significant difference of lactic acid levels between the SIRS and MODS group with $p=0.036$ $(p<0.05)$. However, in the sepsis and severe sepsis there was no significant difference of lactic acid levels with $p=0.771(p>0.05)$. A significant difference in at least two sepsis groups indicated a need to carry out the correlation test to determine the correlation 
between lactic acid level and sepsis severity degree.

From the results of the Pearson correlation test, the correlation coefficient ( $r$ ) of 0.414 $(p=0.023<0.05)$ and the determination coefficient (r2) of 0.171 were obtained, suggesting a sufficient correlation between lactic acid levels and sepsis severity degree and each change of sepsis severity degree as much as $17.1 \%$ was caused by an increase of lactic acid level, respectively. Furthermore, and the correlation coefficient of 0.414 also showed a positive correlation suggesting that the neonatal sepsis severity increased along with the increase of the lactic acid levels.

The ROC curve analysis of lactic acid levels based on the sepsis severity degree can be seen in Figure 1. The AUC value of lactic acid measurement in suspected sepsis patients was $60.6 \%$ with a $95 \%$ confidence interval between $0.369-0.843$. The AUC value of $60.6 \%$ was categorized as a moderate value.

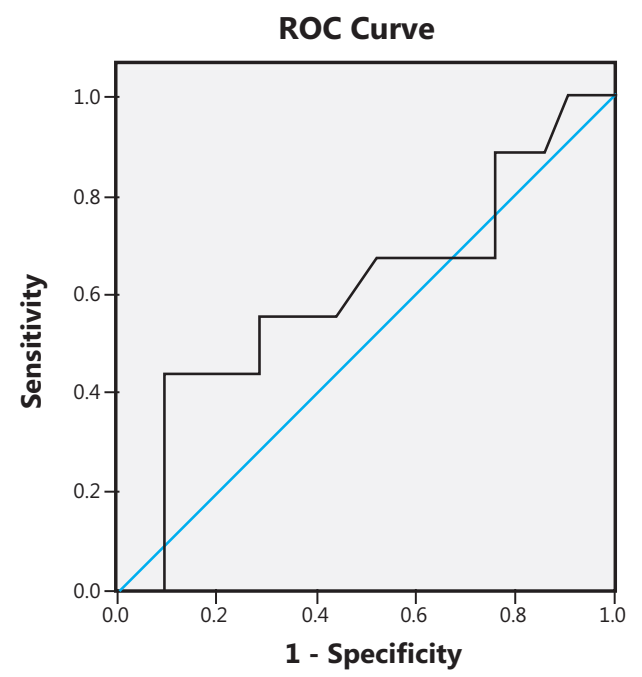

Figure 1. The ROC curve analysis of lactic acid levels based on the sepsis severity degree

From the sensitivity and specificity curves in Figure 1, the lactic acid level which was recommended for sepsis suspected patients in this study showed the cut-off value of $3.10 \mathrm{mmol} / \mathrm{L}$. Both curves were intersected at a value of $3.10 \mathrm{mmol} / \mathrm{L}$ with a sensitivity of $55.6 \%$ and specificity of $57.1 \%$.

However, the better results were obtained at the cut-off $\geq 2.5 \mathrm{mmol} / \mathrm{L}$ with a sensitivity of $66.7 \%$ and specificity of $76.2 \%$. Analysis using a $2 \times 2$ table with reference to the patients' outcome showed sensitivity, specificity, and positive predictive value were $66.7 \%, 76.2 \%$, and $27.3 \%$, respectively.

From the Chi-Square test result, 4 patients (44.4\%) with lactic acid levels $>5 \mathrm{mmol} / \mathrm{L}$ was reported to die, while the other 3 patients (14.3\%) with lactic acid
Table 1. The correlation between lactic acid level and the patients'outcomes

\begin{tabular}{llcc}
\hline \multirow{2}{*}{$\begin{array}{l}\text { Lactic acid } \\
\text { cut-off value }\end{array}$} & \multicolumn{3}{c}{ Outcome } \\
\cline { 2 - 4 } & Died & Survived & Total \\
\hline$\geq 2.5 \mathrm{mmol}$ & 6 & 16 & 22 \\
$<2.5 \mathrm{mmol}$ & 3 & 5 & 8 \\
Total & 9 & 21 & 30 \\
\hline
\end{tabular}

level $>5 \mathrm{mmol} / \mathrm{L}$ was reported to survive. Furthermore, 5 patients (55.5\%) with lactic acid levels $<5 \mathrm{mmol} / \mathrm{L}$ were reported to die, while the other 18 patients (85.7\%) with lactic acid levels $<5 \mathrm{mmol} / \mathrm{L}$ were reported to survive. P-value of $0.073(p>0.05)$ suggested that there was no correlation between lactic acid level> $5 \mathrm{mmol} / \mathrm{L}$ and the patients'outcomes (Table 1 ).

The strength of association between the parameters was determined as the Odd Ratio (OR), which was equal to 4.8 with confidence interval of $95 \%(0.797-28,898)$. This meant that patients with a lactic acid level of $>5 \mathrm{mmol} / \mathrm{L}$ were 4.8 times more likely to die compared to patients with lactic acid levels $<5 \mathrm{mmol} / \mathrm{L}$.

From the Chi-Square test, lactic acid levels of $>2$ $\mathrm{mmol} / \mathrm{L}$ were found in 8 patients $(88.9 \%)$ who died and in 18 patients (85.7\%) who lived people. Furthermore, lactic levels of $<2 \mathrm{mmol} / \mathrm{L}$ were found in 1 patient (11.1\%) who died and 3 patients (14.3\%) who lived. The $p$ value of $0.815(p>0.05)$ meant that there was no correlation between the lactic acid level $>2 \mathrm{mmol} / \mathrm{L}$ and the patients'outcomes. The strength of the association between the parameters was determined as $\mathrm{OR}$, which was equal to 1.33 with confidence interval of $95 \%(0.120-14,868)$. This meant that patients with lactic acid levels $>2 \mathrm{mmol} / \mathrm{L}$ had were 1.3 times like to have die compared to patients with lactic acid levels $<2 \mathrm{mmol} / \mathrm{L}$.

After analyzed using the Pearson correlation test, $r 2=0.171(p=0.023 ;<0.05)$ was obtained, suggesting that the lactic acid level affected the sepsis degree as much as $17.1 \%$, although the value was classified as weak, it indicated that the lactic acid levels had a correlation with neonatal sepsis severity degree. This was similar to a study conducted at the Hasan Sadikin Hospital, Bandung, by Dharma et al. from April to May 2008 in the Department of Paediatrics and Child Health suggesting a significant correlation between sepsis severity degree and lactic acid levels based on the Spearman correlation test $(p \text {-value }=0.033)^{8}{ }^{8}$

From the linear regression analysis with $p$-value 
of $0.023(p<0.05)$, each increase of one degree of sepsis severity led to an increase of lactic acid of $0.151 \mathrm{mmol} / \mathrm{L}$. The increase of lactic acid levels in sepsis patients indicated an increase of continuous change in glycolysis based on a hypermetabolic circumstance, whereas in a septic shock circumstance the continuous change in glycolysis was based on hypoxia tissue. If the normal lactic acid level in the body is 0.3 to $1.0 \mathrm{mmol} / \mathrm{L}$, an increase of blood lactic acid levels above $2 \mathrm{mmol} / \mathrm{L}$ will lead to hyperlactatemia. ${ }^{10-12}$

ROC curve analysis with the value of $60.6 \%$ showed that if the lactic acid level was used to determine the outcome of sepsis in 100 patients, the exact conclusions would only be obtained in 61 patients. The $p$-value $>0.05$ indicated that the potential of lactic acid area under the curve (AUC) to determine the outcome of sepsis patients was not significantly different from the $50 \%$ AUC value.

The cut-off value used in this study was $\geq 2.5 \mathrm{mmol} / \mathrm{L}$ with a sensitivity, specificity, and positive predictive value were $66.7 \%, 76.2 \%$, and $27.3 \%$, respectively. The sensitivity of $66.7 \%$ showed that out of 100 patients who had died, only 67 people had high lactic acid levels. The specificity of $76.2 \%$ indicated that lactic acid level could confirm $76.2 \%$ surviving neonates. A positive predictive value of $75 \%$ meant that patients with lactic acid levels $\geq 2.5 \mathrm{mmol} / \mathrm{L}$ had $27.3 \%$ probability to die. This meant that the lactic acid levels $\geq 2.5 \mathrm{mmol} / \mathrm{L}$ were not able to certainly determine the life or death of neonatal sepsis patients, which was contrast to a study conducted on serum lactic acid level as a predictor of the septic shock circumstance in pediatrics. It was found that lactic acid levels $>45 \mathrm{mg} / \mathrm{dL}$ ( $5 \mathrm{mmol} / \mathrm{L}$ ) would predict mortality at a significant level. ${ }^{10}$

Based on the Chi-Square test, lactic acid level $>5 \mathrm{mmol} / \mathrm{L}$ with a $p$-value of $0.073(p>0.05)$ was obtained, suggesting no correlation between the lactic acid level $>5 \mathrm{mmol} / \mathrm{L}$ and the patients'outcomes. However, patients with lactic acid levels $>5 \mathrm{mmol} / \mathrm{L}$ were 4.8 times likely to die compared to those with lactic acid levels $<5 \mathrm{mmol} / \mathrm{L}$.

Similarly, results at lactic acid levels $>2 \mathrm{mmol} / \mathrm{L}$ with the $p$-value of $0.815(p>0.05)$ suggested no correlation between lactic acid level $>2 \mathrm{mmol} / \mathrm{L}$ and patients'outcomes. In addition, patients with lactic acid levels $>2 \mathrm{mmol} / \mathrm{L}$ showed 1.3 times probability of death compared to patients with lactic acid levels $<2 \mathrm{mmol} / \mathrm{L}$.

Similar results were shown by previous studies with data as follows: from first lactic acid levels measurement, there were 3 subjects with lactic acid levels < $18 \mathrm{mg} / \mathrm{dL}$ ( $2 \mathrm{mmol} / \mathrm{L})$ and all survived; ; 7 subjects ( 6 died and 1 survived) with lactic acid levels of $18-45 \mathrm{mg} / \mathrm{dL}(2-5 \mathrm{mmol} / \mathrm{L})$; and 16 subjects (10 died and 6 survived) with lactic acid levels $>45 \mathrm{mg} / \mathrm{dL}$ ( $5 \mathrm{mmol} / \mathrm{L})$.. From the second lactic acid levels measurement, there were 5 subjects ( 1 died and 4 survived) with lactic acid levels $<18 \mathrm{mg} / \mathrm{dL}$ ( $2 \mathrm{mmol} / \mathrm{L}$ ) of five (5); 7 subjects ( 1 died and 6 survived) with lactic acid levels of $18-45 \mathrm{mg} / \mathrm{dL}$ ( $2 \mathrm{mmol} / \mathrm{L}-5 \mathrm{mmol} / \mathrm{L}$ ); and 14 subjects (10 died and 4 survived) with lactic acid levels $>45 \mathrm{mg} / \mathrm{dL}$. Lastly, from the third lactic acid levels measurement there were 6 subjects ( 1 died and 5 survived) with lactic acid levels < $18 \mathrm{mg} / \mathrm{dL}$ ( $2 \mathrm{mmol} / \mathrm{L}) ; 6$ subjects ( 1 died and 5 survived) with lactic acid levels of $18-45 \mathrm{mg} / \mathrm{dL}$ ( $2 \mathrm{mmol} / \mathrm{L}-5 \mathrm{mmol} / \mathrm{L}$ ); and 11 subjects $(7 \mathrm{dead}$ and 4 survived) with lactic acid levels $>45 \mathrm{mg} / \mathrm{dL}$ $(5 \mathrm{mmol} / \mathrm{L}){ }^{10}$

The results of this study were thought to be influenced by the presence of confounding factors that caused an increase of lactic acid levels exceeding the normal limit. Some subjects, however, still showed good outcomes regardless of lactic acid levels. The confounding factors were drugs, current therapy, presence or absence of shock circumstances, malignancy or other associated diseases. ${ }^{12}$

\section{CONCLUSION AND SUGGESTION}

There was a significant correlation between lactic acid levels and sepsis severity degree in which level affected the sepsis degree of $17.1 \%$ and at each increase in one degree of neonatal sepsis, there was an increase in lactic level of $0.151 \mathrm{mmol} / \mathrm{L}$. The prognostic value obtained by examining the lactic level with a cut-off of $\geq 2.5 \mathrm{mmol} / \mathrm{L}$ was not sensitive, but more specific for the determination of the neonatal sepsis prognosis (sensitivity of $66.7 \%$ and specificity of $76.2 \%$ ). The patients with a lactic acid level of $>2 \mathrm{mmol} / \mathrm{L}$ showed a 1.3 times of odds to have died compared to patients with lactic acid levels $<2 \mathrm{mmol} / \mathrm{L}$. But patients with lactic acid levels $>5 \mathrm{mmol} / \mathrm{L}$ were 4.8 times likely to have die compared to those with lactic acid levels $<5 \mathrm{mmol} / \mathrm{L}$. The lactic acid levels of $>5 \mathrm{mmol} / \mathrm{L}$ could be used to determine death of neonatal sepsis patients.

It was suggested for further studies about lactic acid level, its correlation with neonatal sepsis severity, and its prognostic test to use more subjects. Studies for determining neonatal sepsis prognosis can be related to other biomarker examinations. 


\section{REFERENCES}

1. Pusponegoro TS. Sepsis pada neonatus (sepsis neonatal). Sari Pediatri, 2000; 2(2): 96-102.

2. Gerdes JS. Diagnosis and management of bacterial infections in the neonate. Elsevier Saunders, 2004; 51: 939-957.

3. Kaban RK. Salah satu penanganan bayi prematur yang perlu diketahui. Diakses dari:http://idai.or.id/publicarticles/seputar-kesehatan-anak/salah-satupenanganan-bayi-prematur-yang-perludiketahui.html. 2014 (Acssessed on 28 May, 2015).

4. Thaver D, Zaidi AKM. Burden of neonatal infections in developing countries. The Pediatric Infectious Disease Journal, 2009; 28(1): S3-S9.

5. Biron BM, Ayala A, Lomas-Neira JL. Biomarkers for sepsis: What is and what might be? Libertas Academica, 2015; 10(4): 7-17.

6. Andersen WL, Mackenhauer J, Roberts JC, Berg KM, Cocchi MN, Donnino MW. Etiology and therapeutic approach to elevated lactate. Mayo Clin Proc, 2013;
88(10): 1127-1140.

7. Patriawati KA. Kadar Laktat serial sebagai faktor prognosis mortalitas pasien sepsis (Abstrak). Yogyakarta, Universitas Gadjah Mada, 2013.

8. Dharma AB, Rosalina I, Sekarwana N. Hubungan kadar laktat plasma dengan derajat disfungsi organ berdasarkan skor PELOD pada anak sakit kritis. Sari Pediatri, 2008; 10(4): 280-283.

9. Dahlan MS. 2014. Statistik untuk kedokteran dan kesehatan, Edisi 6., Epidemiologi Indonesia, Jakarta, Salemba Medika, 2014; 225-234.

10. Jat RK, Jhamb U, Gupta VK. Serum lactate levels as the predictor of outcome in pediatric septic shock. Indian Journal of Critical Care Medicine, 2011; 15(2): 102-107.

11. Zeichner SL, Read JS. Textbook of pediatric HIV care. New York, Cambridge University Press, 2005; 93-95.

12. Hernández G, Bruhn $A$, Castro $R$, Pedreros $C$, Rovegno $M$, et al. Persistent sepsis-induced hypotension without hyperlactatemia: is it really septic shock?. Journal of Critical Care, 2011; 26(4): 435.e9-435.e14. 